\title{
Open minded and open access: introducing NeoBiota, a new peer-reviewed journal of biological invasions
}

Ingolf Kühn', Ingo Kowarik², Johannes Kollmann³ , Uwe Starfinger ${ }^{4}$, Sven Bacher $^{5}$, Tim M. Blackburn ${ }^{6}$, Ramiro O. Bustamante ${ }^{7}$, Laura Celesti-Grapow ${ }^{8}$, Milan Chytrý, Robert I. Colautti ${ }^{10}$, Franz Ess' ${ }^{11}$, Llewellyn C. Foxcroft ${ }^{12,13}$, Emili García-Berthou ${ }^{14}$, Stephan Gollasch ${ }^{15}$, José Hierro ${ }^{16}$, Ruth A. Hufbauer ${ }^{17}$, Philip E. Hulme ${ }^{18}$, Vojtěch Jarošík ${ }^{19,20}$, Jonathan M. Jeschke ${ }^{21}$, Gerhard Karrer ${ }^{22}$, Richard N. Mack ${ }^{23}$, Jane Molofsky²4, Brad R. Murray ${ }^{25}$, Wolfgang Nentwig ${ }^{26}$, Bruce Osborne ${ }^{27}$, Petr Pyšek ${ }^{20,19}$, Wolfgang Rabitsch ${ }^{10}$, Marcel Rejmánek ${ }^{28}$, Alain Roques $^{29}$, Richard Shaw ${ }^{30}$, Daniel Sol ${ }^{31}$, Mark van Kleunen ${ }^{32}$, Montserrat Vilà̀ ${ }^{33}$, Moritz von der Lippe ${ }^{2}$, Lorne M. Wolfe ${ }^{34}$, Lyubomir Penev ${ }^{35}$

I UFZ, Helmholtz Centre for Environmental Research - UFZ, Dept. Community Ecology, Theodor-LieserStr. 4, 06120 Halle, Germany 2 Department of Ecology, Technische Universität Berlin, Rothenburgstr. 12, 12165 Berlin, Germany 3 Restoration Ecology, Technische Universität München, Emil-Ramann-Straße 6, 85354 Freising, Germany 4 Julius Kuehn Institute, Federal Research Centre for Cultivated Plants, Institute for National and International Plant Health, Messeweg 11-12, 38104 Braunschweig, Germany 5 Department of Biology, Ecology \& Evolution Unit, University of Fribourg, Ch. du Musée 10, CH-1700 Fribourg, Switzerland 6 Institute of Zoology, ZSL, Regent's Park, London NW1 4RY, UK; and Distinguished Scientist Fellowship Program, King Saud University, P.O. Box 2455, Riyadh 1145, Saudi Arabia 7 Department of Ecological Sciences, Institute of Ecology and Biodiversity, University of Chile, Santiago, Chile 8 Department of Environmental Biology, Sapienza University, piazzale Moro, 00185 Rome, Italy 9 Department of Botany and Zoology, Masaryk University, Kotlárská 2, 61137 Brno, Czech Republic 10 Biology Department, Duke University, Box 90338, Durham, NC 27708, USA II Environment Agency Austria, Department of Biodiversity and Nature Conservation, Spittelauer Lände 5, 1090 Vienna, Austria 12 Conservation Services, South African National Parks, Private Bag X 402, Skukuza 1350, South Africa 13 DST-NRF Centre for Invasion Biology, Department of Botany and Zoology, Stellenbosch University, Private Bag X1, Matieland 7602, South Africa 14 Institute of Aquatic Ecology, University of Girona, 17071 Girona, Catalonia, Spain 15 GoConsult, Große Brunnenstrasse 61, 22763 Hamburg, Germany 16 CONICET-Universidad Nacional de La Pampa, Facultad de Ciencias Exactas y Naturales, Av. Uruguay 151, 6300 Santa Rosa, La Pampa, Argentina 17 Department of Bioagricultural Science and Pest Management and Graduate Degree Program in Ecology, Colorado State University, Fort Collins, CO 80523, USA 18 The Bio-Protection Research Centre, PO Box 84, Lincoln University, Christchurch, New Zealand 19 Department of Ecology, Faculty of Science, Charles University in Prague, Viničná 7, 12844 Prague 2, Czech Republic 20 Institute of Botany, Academy of Sciences of the Czech Republic, 25243 Prihonice, Czech Republic 21 Ludwig-Maximilians-University Munich, Department of Biology II, Ecology, Grosshaderner Str. 2, 82152 Planegg-Martinsried, Germany

Copyright Ingolf Kühn et al. This is an open access article distributed under the terms of the Creative Commons Attribution License, which permits unrestricted use, distribution, and reproduction in any medium, provided the original author and source are credited. 
22 Department of Integrative Biology and Biodiversity Research, University of Natural Resources and Life Sciences Vienna, Gregor Mendel Str. 33, 1180 Vienna, Austria 23 School of Biological Sciences, Washington State University, Pullman, WA 99164, USA 24 Department of Plant Biology, University of Vermont, Burlington, Vermont, USA, 0540525 School of the Environment, University of Technology Sydney, PO Box 123, NSW 2007, Australia 26 Institute of Ecology and Evolution, University of Bern, Baltzerstrasse 6, 3012 Bern, Switzerland 27 UCD School of Biology and Environmental Science, University College Dublin, Belfield, Dublin 4, Ireland 28 Department of Evolution and Ecology, University of California, Davis, CA 95616, USA 29 INRA UR 633, Zoologie Forestière, 2163 Avenue de la Pomme de Pin, 45075 Orléans, France 30 CABI Europe - UK Centre, Bakeham Lane, Egham, Surrey, TW20 9TY, England 3 I CREAF (Centre for Ecological Research and Applied Forestries), Spanish National Research Council, Autonomous University of Barcelona, Bellaterra, Catalonia 08193, Spain 32 Estación Biológica de Doñana (EDB-CSIC), Avda. Américo Vespucio, s/n, 41092 Sevilla, Spain 33 Ecology, Department of Biology, University of Konstanz, Universitätsstrasse 10, 78457 Konstanz, Germany 34 Department of Biology, Georgia Southern University, Statesboro, GA 30460, USA 35 Pensoft Publishers, 13a Geo Milev Street, 1111 Sofia, Bulgaria

Corresponding authors: IngolfKühn (Ingolf.kuehn@ufz.de), Lyubomir Penev (info@pensoft.net)

Received 21 July 2011 | Accepted 25 July 2011 | Published 11 August 2011

Citation: Kühn I, Kowarik I, Kollmann J, Starfinger U, Bacher S, Blackburn TM, Bustamante RO, Celesti-Grapow L, Chytrý M, Colautti RI, Essl F, Foxcroft LC, García-Berthou E, Gollasch S, Hierro J, Hufbauer RA, Hulme PE, Jarošík V, Jeschke JM, Karrer G, Mack RN, Molofsky J, Murray BR, Nentwig W, Osborne B, Pyšek P, Rabitsch W, Rejmánek M, Roques A, Shaw R, Sol D, Vilà M, van Kleunen M, von der Lippe M, Wolfe LM, Penev L (2011) Open minded and open access: introducing NeoBiota, a new peer-reviewed journal of biological invasions. NeoBiota 9: 1-11. doi: 10.3897/neobiota.9.1835

\begin{abstract}
The Editorial presents the focus, scope, policies, and the inaugural issue of NeoBiota, a new open access peer-reviewed journal of biological invasions. The new journal NeoBiota is a continuation of the former NEOBIOTA publication series. The journal will deal with all aspects of invasion biology and impose no restrictions on manuscript size neither on use of color. NeoBiota implies an XML-based editorial workflow and several cutting-edge innovations in publishing and dissemination, such as semantic markup of and enhancements to published texts, data publication, and extensive cross-linking within the journal and to external sources.
\end{abstract}

\title{
Keywords
}

NeoBiota, invasion biology, alien species, semantic markup, semantic enhancements, data publishing

\section{Introduction}

Introduced species have significant biodiversity impacts across all scales ranging from individual genes to global species declines that are shaped by a range of evolutionary, ecological, economic and societal mechanisms. As a consequence, biological invasions are a major challenge for current research, policy development and stakeholder response. International trade, transport and travel cause an ever faster increase in alien 


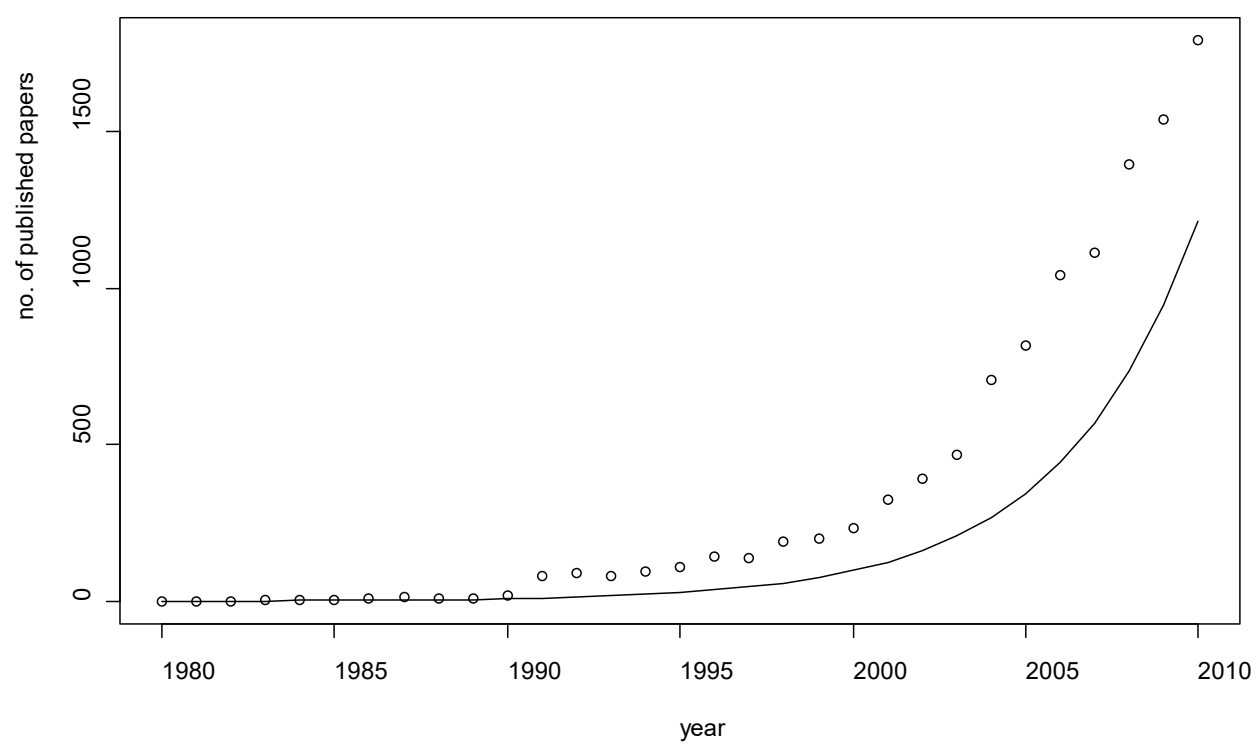

Figure I. The number of papers on alien or invasive species published per year (1980-2010) according to ISI Web of Science (accessed 1 July 2011, search string: topic=[alien plant* or alien animal* or alien species or biological invasions or plant invasions or animal invasions or "invasive species"]). The line indicates fitted exponential increase $\left(\mathrm{R}^{2}=0.96, \mathrm{p}<0.0001\right)$.

species numbers (Hulme 2009; Pyšek et al. 2010; Chytrý et al. in press), while at the same time 'invasion debts' due to past socio-economic processes (Essl et al. 2011) provide ongoing and emerging challenges. Thus, research on alien species is a broad and innovative field of eminent importance from both theoretical and applied perspectives (Pyšek et al. 2006; Richardson and Pyšek 2008), and not surprisingly number of peerreviewed papers published in the last 30 years has been rising exponentially (Fig. 1).

Despite much success in research on invasion biology, some scientists have claimed that this type of specialized research is uninformative and have suggested that it be integrated into more general ecological sub-disciplines (Marris 2009; Davis et al. 2011; Thompson and Davis 2011), which was vigorously opposed (e.g. Pyšek and Hulme 2009; Hulme et al. 2011; Simberloff et al. 2011; van Kleunen et al. 2011). Although the search for general patterns and mechanisms in ecology should be continued, this recommendation is oversimplified since biological invasions have become a general phenomenon in themselves shaping our views of evolutionary, molecular, restoration, population and community ecology (Simberloff and Rejmánek 2011). Of course, basic ecological patterns and processes are most likely similar for all species independent of their origin, but depending on the specific questions and geographic locations there are pronounced differences between native and alien species in their life-history traits (Crawley et al. 1996; Hovick et al. 2011), dispersion (Hulme 2008) and response to environmental drivers (Walther et al. 2009). While many alien species have negative ecological and economic impacts (Vilà et al. 2010), others may currently have no discernable effects 
(Williamson 1996; Kenis et al. 2009; Kowarik 2010), and significant number of introduced species, mostly plants, have proved beneficial in the agricultural, horticultural and forestry sectors (Kühn and Klotz 2003; Lambdon et al. 2008). We can also expect that introduced species will continue to have an important role in the provision of food, fibre and fuel and contribute positively to 'novel ecosystems' that fulfil certain ecological functions in degraded habitats (Hobbs et al. 2006; Pyšek and Richardson 2010; Kowarik 2011), or in a changed climate (Walther et al. 2009). Thus, invasion biology has many important questions and promising areas that remain for future balanced analyses, and certainly it is a discipline too vigorous to die (Pyšek et al. 2008; Pyšek and Hulme 2009).

We therefore are confident that the field will thrive in the future. Some of the promising current and future topics we see are:

Mechanisms underlying biological invasions:

- How propagule pressure drives establishment success in different taxa and environmental circumstances.

- The impact on the invasion process of filters acting on individuals and species prior to them reaching novel environments.

- Quantification of dispersal mechanisms and vectors of introduction and spread.

- Traits that distinguish invasive alien species from non-invasive alien species and native species; relationship between species traits and invasion success.

- Importance of life history trade-offs along different stages of the invasion process.

- Demographic processes and the abiotic and biotic factors shaping them between native and introduced ranges of species.

- Relative importance of founding population size vs. genetic diversity in the establishment of new populations.

- Genetics and genomics of adaptation in invasive alien species.

- Climatic niche conservatism and the biogeography of invasive species.

- Effects of other global change components on biological invasions and interaction of invasions with such drivers, in first place climate change.

- Assembly rules and functioning of invaded biotic communities; mechanisms that allow alien species to coexist with native species.

- Mutualism or facilitation during the different steps of the invasion process.

- Invasiveness of understudied groups of organisms. Epidemiology of alien pathogens and parasites (e.g. fungi and micro-organisms).

- Comparisons of different 'novel organisms', especially alien species and genetically modified organisms.

- Quantifying the strength of biotic resistance to invasions among communities. Differences in invasibility of ecosystem types and their causes (e.g. disturbance, fragmentation).

- Harmonizing the different approaches that have been developed in different taxonomic groups into a common framework that allow true cross-taxon analyses of the factors driving the different steps of the invasion process (e.g. Blackburn et al. 2011). 
Consequences of biological invasions at different scales:

- Post-invasion microevolution in native and alien species, including hybridization.

- Large-scale assessment of biodiversity changes at the gene and populations levels.

- Impacts on economy, human, plant and animal health; facilitation of human pathogens by alien species; ecosystem impacts ("changes in" biogeochemical cycles, flammability).

- Eco-evolutionary feedback between invasive traits and ecosystem function.

- Macroecological patterns of invasions at different scales and interaction among factors shaping them.

- Context dependence of invasion success and impacts.

- Impacts on endangered species and protected areas including long-term studies.

Assessing biological invasions:

- Taxonomic impediment and the need of correct identification of species.

- Standardization of collecting and storing data and of assessing invasion impacts to allow comparability across regions.

- Modelling tools to predict spatial spread of invasive species.

- Statistical techniques to account for biases and confounding factors; effects of data deficiency on the perception of factors associated with invasion success.

- Interface between scientifically backed analyses and value-based assessments of invasion consequences.

- Novel ecosystems and how to define and approach them.

- Ecosystem services and disservices

- Risk-assessment tools, developed for independent purposes at different scales.

Managing biological invasions:

- Social and political aspects of biological invasions.

- Control or management of introduction vectors to avoid further species to arrive.

- Ballast water management and compliance control technologies to assess whether standards were met.

- Rapid practical implementation of advances in invasion biology for prevention, eradication, and control of alien species.

- Restoration of invaded habitats and management of novel ecosystems.

- Risk analyses, black lists and other prevention tools.

- Legal measures and their implementation.

\section{Why 'NeoBiota'?}

While the publication of Elton's (1958) book The Ecology of Invasions by Animals and Plants is often considered the pioneering milestone in modern invasion ecology (Ricciardi and MacIsaac 2008; Richardson and Pyšek 2008), the European tradition in re- 
search on biological invasions is actually older and rooted in botanical studies from the beginning of the 19th century (see Trepl 1990; Kowarik and Starfinger 2009). However, European research on invasions, for example in Germany, was fragmented until the end of the 20th century with little cooperation between plant and animal ecologists and those working on terrestrial, freshwater and marine ecosystems, or on the pure and applied sciences (Kowarik and Starfinger 2009). To address this situation, a first meeting of invasion biologists was convened in Berlin in 1999 with the aim of integrating all aspects of invasion research, with the ultimate goal of reducing the threats to biological diversity. From this meeting arose an informal association of scientists, whose aims were: (i) to enhance communication and contact among scientists working on theoretical and applied aspects of biological invasions; (ii) to stimulate research on non-native species, their traits, distribution, related impacts and underlying mechanisms; (iii) to identify information deficits and co-ordinate efforts to fill them; and (iv) to disseminate information on causes, mechanisms and impacts of biological invasions, and on management approaches.

The resulting group was named 'NEOBIOTA', coined as an overarching term that would encompass all groups of organisms and avoid negative associations (Kowarik and Starfinger 2009). Terms such as 'invasion', 'alien' or 'exotic' were discounted as having negative connotations, since the group was interested not just in problematic non-native species, but also in species with neutral or beneficial impacts. Kowarik (2002) defined „neobiota as organisms, independent of their taxonomic rank, that occur in a region beyond their native range due to human agency or that evolved from such taxa". Hence, neobiota is an umbrella term for all non-native species without defining these by a negative or a value laden approach. Quite quickly, NEOBIOTA developed from a German to a Central-European and then pan-European working network with biennial conferences (see Kowarik and Starfinger 2009 for details). During the 6th NEOBIOTA conference in Copenhagen in 2010, the participants agreed on launching an international, peer-reviewed journal, named NeoBiota, and advocated for an open-access platform.

The new journal NeoBiota is a continuation of the former NEOBIOTA publication series, therefore it starts with No 9. Volumes 1-8 of NEOBIOTA can be seen at: http://www.oekosys.tu-berlin.de/menue/neobiota.

\section{Why a new journal?}

In face of the eminent and increasing importance of biological invasions there is demand for a new journal that provides open access to a broad array of theoretical and applied invasion topics across all taxa and ecosystems. A further significant reason to launch a new journal is the need to respond to the major technological shift in academic publishing practices during last decade which will ensure important advantages for both authors and readers.

The new journal NeoBiota publishes papers without size limits across all disciplines dealing with biological invasions, encompassing the ecology, evolution and biogeogra- 
phy of non-native aquatic and terrestrial animals, plants, fungi and microorganisms, on mechanisms that drive the introduction, establishment and spread of these species, on ecological, evolutionary, economic and other consequences of biological invasions, and on the management of invasions in any part of the world. No bias will be attached to the impact of non-native species, whether it is negative or positive, and all aspects related to a particular topic will be considered. NeoBiota therefore also strongly encourages papers on ethical, social, legal and policy issues related to biological invasions. NeoBiota considers the following categories of papers for publication: (i) original research articles, (ii) reviews as longer articles that offer a comprehensive overview, historical analysis or future perspectives of a topic, (iii) monographs and collections of papers on a specific topic with no limit in size, published as 'special issues', (iv) short communications, letters and discussion papers, and (v) book reviews.

The articles selected for the inaugural issue of NeoBiota largely reflect the vision of the editors of encouraging innovative and timely contributions to the new journal. The paper of Mack and Smith (2011), for example, addresses the increasingly important interface between biological invasions and human health by illustrating the role of invasive plants for spreading human parasites. The contribution by Moravcová et al. (2011) sheds light on interactions between introduced and native species by demonstrating potential phytotoxic effects of invasive Fallopia taxa, and Kowarik and von der Lippe (2011) disentangle, by using an experimental approach, the functioning of secondary wind dispersal in traffic corridors from that of other vectors. Finally, the contribution by Guo (2011) addresses, as a critical methodological challenge, how to count exotics at different spatial scales.

\section{Why innovative and open access?}

The past decade has witnessed an unprecedented revolution in the way science is published and communicated. This revolution is driven by the Internet as a new media and communication environment and by open access publishing models (Suber 2010). Currently, we see the rapid move to the semantic Web (Web 2.0) and linked data environments (Berners-Lee et al. 2006), as well as an increasing strength of the open knowledge movement (see Open Knowledge/Data Definition and Panton Principles for Open Data in Science). The 'journals of the future' are meant mostly as various kinds of social networks, serving the interested community and reaching out to a wider audience, providing barrier-free, express and concise information, as well as access to underlying data. Content published in the journals of the next generation will be linked to various related sources and automatically distributed through community networks, wiki environment, indexing and aggregation services. An important trend with expected major impact on science communication is the 'atomization' of the content, that is dissemination both at the level of individual articles, as well as at the level of intrinsic parts of an article, such as taxon treatments, locality records, habitat descriptions, and others. 
By having opted for open access and use of innovative publishing and dissemination methods applied in Pensoft's journals (see for more detail: Penev et al. 2009, 2010a, b, 2011), we intend to make NeoBiota a rapid means of communication with a quick editorial turnaround and time-to-publication process, as well as an efficient system of cross-linking of published content to external biodiversity and bibliographic platforms.

Thus, NeoBiota will respond to the present-day cultural and technological revolution in scholarly publishing and communication through:

- Open access to all scientific content published in the journal, with the barrier-free environment for the dissemination of scientific results, hence increased visibility and citation probability, that will benefit our authors and the scientific community in general.

- Strong support and provision of infrastructure for open data publishing, recognizing the crucial importance of up-to-date information on how to manage biological invasions, whilst facilitating the archiving, use and re-use of data, increasing the efficiency of data sampling-efforts, as well as the overall transparency and quality of the science.

- Development and implementation of various methods for semantic mark-up of and semantic enhancements to published texts, to ensure a pleasant and efficient reading process, as well as wide dissemination of separate parts of an logically 'atomised' article's content.

- Publication of identical content in four different formats to serve different target user groups: (1) full-colour, high-resolution print version; (2) PDF for reference to the printed version and easy archiving; (3) HTML for easy reading, browsing and applying semantic enhancements to the text; and (4) XML to provide a machine-readable file for archiving and data mining.

- Automated cross-linking through the Pensoft Taxon Profile with major indexing and aggregation platforms, such as the Global Biodiversity Information Facility (GBIF), Encyclopedia of Life (EOL), the International Plant Name Index (IPNI), ZooBank, the National Center for Biodiversity Information (NCBI), Genbank and Barcode of Life, the Biodiversity Heritage Library (BHL), PubMed, PubMedCentral, Mendeley and many others.

- Increased public awareness of scientific results on biological invasions through an already established system of press releases associated with published articles, science and general blogs, social networks and others.

With these new techniques and novel publishing methods backing up NeoBiota, we are confident we will contribute successfully to facilitating research and education on invasion biology and to the swift communication of scientific results. By joining forces with an innovative and ambitious publisher we aim to make the science on biological invasions more open, efficient and of great benefit to scientists, research funders and society in general. 


\section{References}

Berners-Lee T, Chen Y, Chilton L, Connolly D, Dhanaraj R, Hollenbach J, Lerer A, Sheets D (2006) Tabulator: Exploring and analyzing linked data on the Semantic Web. Proceedings of the 3rd International Semantic Web User Interaction Workshop. Athens, Georgia. http://citeseerx.ist.psu.edu/viewdoc/download?doi=10.1.1.97.950\&rep=rep1\&type=pdf.

Blackburn TM, Pyšek P, Bacher S, Carlton JT, Duncan RP, Jarošík V, Wilson JRU and Richardson DM (2011) A proposed unified framework for biological invasions. Trends in Ecology and Evolution 26: 333-339. doi: 10.1016/j.tree.2011.03.023.

Chytrý M, Wild J, Pyšek P, Jarošík V, Dendoncker N, Reginster I, Pino J, Maskell LC, Vilà M, Kühn I, Spangenberg JH, Settele J (in press) Projecting trends in plant invasions in Europe under different scenarios of future land-use change. Global Ecology and Biogeography, doi: 10.1111/j.1466-8238.2010.00573.x.

Crawley MJ, Harvey PH, Purvis A (1996) Comparative ecology of the native and alien floras of the British Isles. Philosophical Transactions of the Royal Society of London Series BBiological Sciences 351: 1251-1259.

Davis M, Chew MK, Hobbs RJ, Lugo AE, Ewel JJ, Vermeij GJ, Brown JH, Rosenzweig ML, Gardener MR, Carroll SP, Thompson K, Pickett STA, Stromberg JC, Del Tredici P, Suding KN, Ehrenfeld JG, Grime JP, Mascaro J, Briggs JC (2011) Don't judge species on their origins. Nature 474: 153-154.

Elton C (1958) The ecology of invasions by animals and plants. Methuen, London, 196pp.

Essl F, Dullinger S, Rabitsch W, Hulme PE, Huelber K, Jarošík V, Kleinbauer I, Krausmann F, Kühn I, Nentwig W, Vilà M, Genovesi P, Gherardi F, Desprez-Loustau ML, Roques A, Pyšek P (2011) Socio-economic legacy yields an invasion debt. Proceedings of the National Academy of Sciences of the United States of America 108: 203-207. doi: 10.1073/ pnas. 1011728108 .

Guo Q (2011) Counting “exotics”. NeoBiota 9: 71-73. doi: 10.3897/neobiota.9.1316

Hobbs RJ, Arico S, Aronson J, Baron JS, Bridgewater P, Cramer VA, Epstein PR, Ewel JJ, Klink CA, Lugo AE, Norton D, Ojima D, Richardson DM, Sanderson EW, Valladares F, Vilà M, Zamora R, Zobel M (2006) Novel ecosystems: theoretical and management aspects of the new ecological world order. Global Ecology and Biogeography 15: 1-7. doi: 10.1111/j.1466-822X.2006.00212.x.

Hovick SM, Bunker DE, Peterson CJ, Carson WP (2011) Purple loosestrife supresses plant species colonization far more than broad-leaved cattail: experimental evidence with plant community implications. Journal of Ecology 99: 225-234.

Hulme PE (2008) Contrasting alien and native plant species-area relationships: the importance of spatial grain and extent. Global Ecology and Biogeography 17: 641-647. doi: 10.1111/j.1466-8238.2008.00404.x.

Hulme PE (2009) Trade, transport and trouble: managing invasive species pathways in an era of globalisation. Journal of Applied Ecology 46: 10-18.

Hulme PE, Pyšek P, Duncan RP (2011) Don't be fooled by a name: a reply to Thompson and Davis. Trends in Ecology \& Evolution 26: 318. 
Kenis M, Auger-Rozenberg MA, Roques A, Timms L, Péré C, Cock MJW, Settele J, Augustin S, Lopez-Vaamonde C (2009) Ecological effects of invasive alien insects. Biological Invasions 11: 21-45.

Kowarik I (2002) Biologische Invasionen in Deutschland: zur Rolle nichteinheimischer Pflanzen. NeoBiota 1: 5-24.

Kowarik I (2010) Biologische Invasionen: Neophyten und Neozoen in Mitteleuropa. 2nd ed., Ulmer, Stuttgart, 492pp.

Kowarik I (2011) Novel urban ecosystems, biodiversity and conservation. Environmental Pollution 159: 1974-1983. doi:10.1016/j.envpol.2011.02.022.

Kowarik I, Starfinger U (2009) Neobiota: a European approach. NeoBiota 8: 21-28.

Kowarik I, von der Lippe M (2011) Secondary wind dispersal enhances long-distance dispersal of an invasive species in urban road corridors. NeoBiota 9: 49-70. doi: 10.3897/neobiota.9.1469

Kühn I, Klotz S (2003) The alien flora of Germany - basics from a new German database. In: Child LE, Brock JH, Brundu G, Prach K, Pyšek P, Wade PM, Williamson M (Eds) Plant invasions: ecological threats and management solutions. Backhuys, Leiden, 89-100.

Lambdon PW, Pyšek P, Basnou C, Hejda M, Arianoutsou M, Essl F, Jarošík V, Pergl J, Winter M, Anastasiu P, Andriopoulos P, Bazos I, Brundu G, Celesti-Grapow L, Chassot P, Delipetrou P, Josefsson M, Kark S, Klotz S, Kokkoris Y, Kühn I, Marchante H, Perglová I, Pino J, Vilà M, Zikos A, Roy D, Hulme PE (2008) Alien flora of Europe: species diversity, temporal trends, geographical patterns and research needs. Preslia 80: 101-149.

Mack RN, Smith MC (2011) Invasive plants as catalysts for the spread of human parasites. NeoBiota 9: 13-29. doi: 10.3897/neobiota.9.1156

Marris E (2009) Invasion biology. Nature 459: 327-328. doi: 10.1038/459327a.

Moravcová L, Pyšek P, Jarošík V, Zákravský P (2011) Potential phytotoxic and shading effects of invasive Fallopia (Polygonaceae) taxa on the germination of native dominant species. NeoBiota 9: 31-47. doi: 10.3897/neobiota.9.1266

Penev L, Agosti D, Georgiev T, Catapano T, Miller J, Blagoderov V, Roberts D, Smith VS, Brake I, Ryrcroft S, Scott B, Johnson NF, Morris RA, Sautter G, Chavan V, Robertson T, Remsen D, Stoev P, Parr C, Knapp S, Kress WJ, Thompson FC, Erwin T (2010a) Semantic tagging of and semantic enhancements to systematics papers: ZooKeys working examples. Zookeys 50: 1-16. doi: 10.3897/zookeys.50.538.

Penev L, Erwin T, Miller J, Chavan V, Moritz T, Griswold C (2009) Publication and dissemination of datasets in taxonomy: ZooKeys working example. ZooKeys 11: 1-8. doi: 10.3897/ zookeys.11.210.

Penev L, Kress WJ, Knapp S, Li D-Z, Renner S (2010b) Fast, linked, and open - the future of taxonomic publishing for plants: launching the journal PhytoKeys. PhytoKeys 1: 1-14. doi: $10.3897 /$ phytokeys.1.642.

Penev L, Hagedorn G, Mietchen D, Georgiev T, Stoev P, Sautter G, Agosti D, Plank A, Balke M, Hendrich L, Erwin T (2011) Interlinking journal and wiki publications through joint citation: Working examples from ZooKeys and Plazi on Species-ID. ZooKeys 90: 1-12. doi: 10.3897/zookeys.90.1369. 
Pyšek P, Hulme PE (2009) Invasion biology is a discipline that's too young to die. Nature 460: 324-324. doi: 10.1038/460324b.

Pyšek P, Jarošík V, Hulme PE, Kühn I, Wild J, Arianoutsou M, Bacher S, Chiron F, Didžiulis

V, Essl F, Genovesi P, Gherardi F, Hejda M, Kark S, Lambdon PW, Desprez-Loustau M-L, Nentwig W, Pergl J, Poboljšaj K, Rabitsch W, Roques A, Roy DB, Shirley S, Solarz W, Vilá M, Winter M (2010) Disentangling the role of environmental and human pressures on biological invasions across Europe. Proceedings of the National Academy of Sciences of the United States of America 107: 12157-12162.

Pyšek P, Richardson DM (2010) Invasive species, environmental change and management, and health. Annual Review of Environment and Resources, Vol 35: 25-55.

Pyšek P, Richardson DM, Jarošík V (2006) Who cites who in the invasion zoo: insights from an analysis of the most highly cited papers in invasion ecology. Preslia 78: 437-468.

Pyšek P, Richardson DM, Pergl J, Jarošík V, Sixtová Z, Weber E (2008) Geographical and taxonomic biases in invasion ecology. Trends in Ecology \& Evolution 23: 237-244. doi: 10.1016/j.tree.2008.02.002.

Ricciardi A, MacIsaac HJ (2008) The book that began invasion ecology. Nature 452: 34.

Richardson DM, Pyšek P (2008) Fifty years of invasion ecology - the legacy of Charles Elton. Diversity and Distributions 14: 161-168. doi: 10.1111/j.1472-4642.2008.00464.x.

Simberloff D, Alexander J, Allendorf F, Aronson J, Antunes PM, Bacher S, Bardgett R, Bertolino S, Bishop M, Blackburn TM, Blakeslee A, Blumenthal D, Bortolus A, Buckley R, Buckley Y, Byers J, Callaway RM, Campbell F, Campbell K, Campbell M, Carlton JT, Cassey P, Catford J, Celesti-Grapow L, Chapman J, Clark P, Clewell A, Clode JC, Chang A, Chytrý M, Clout M, Cohen A, Cowan P, Cowie RH, Crall AW, Crooks J, Deveney M, Dixon K, Dobbs FC, Duffy DC, Duncan R, Ehrlich PR, Eldredge L, Evenhuis N, Fausch KD, Feldhaar H, Firn J, Fowler A, Galil B, Garcia-Berthou E, Geller J, Genovesi P, Gerber E, Gherardi F, Gollasch S, Gordon D, Graham J, Gribben P, Griffen B, Grosholz ED, Hewitt C, Hierro JL, Hulme P, Hutchings P, Jarošík V, Johnson C, Johnson L, Johnston EL, Jones CG, Keller R, King CM, Knols BGJ, Kollmann J, Kompas T, Kotanen PM, Kowarik I, Kühn I, Kumschick S, Leung B, Liebhold A, MacIsaac H, Mack R, McCullough DG, McDonald R, Merritt DM, Meyerson L, Minchin D, Mooney HA, Morisette JT, Moyle P, Müller-Schärer H, Murray BR, Nehring S, Nelson W, Nentwig W, Novak SJ, Occhipinti A, Ojaveer H, Osborne B, Ostfeld RS, Parker J, Pederson J, Pergl J, Phillips ML, Pyšek P, Rejmánek M, Ricciardi A, Ricotta C, Richardson D, Rilov G, Ritchie E, Robertson PA, Roman J, Ruiz G, Schaefer H, Schaffelke B, Schierenbeck KA, Schmitz DC, Schwindt E, Seeb J, Smith LD, Smith GF, Stohlgren T, Strayer DL, Strong D, Sutherland WJ, Therriault $\mathrm{T}$, Thuiller W, Torchin $\mathrm{M}$, van der Putten W, Vilà $\mathrm{M}$, Von Holle B, Wallentinus I, Wardle D, Williamson M, Wilson J, Winter M, Wolfe LM, Wright J, Wonham M, Zabin C (2011) Non-natives: 141 scientists object. Nature 475: 36. doi: 10.1038/475036a.

Simberloff D, Rejmánek M (2011) Encyclopedia of biological invasions. University of California Press, Berkely, CA, 765pp.

Suber P (2010) Open Access Overview: Focusing on open access to peer-reviewed research articles and their preprints. http://www.earlham.edu/ - peters/fos/overview.htm. 
Thompson K, Davis MA (2011) Why research on traits of invasive plants tells us very little. Trends in Ecology \& Evolution 26: 155-156. doi: 10.1016/j.tree.2011.01.007.

Trepl L (1990) Research on the anthropogenic migration of plants and naturalization. Its history and current state of development. In: Sukopp H, Hejný S, Kowarik I (Eds) Urban ecology. Plants and plant communities in urban environments. SPB Academic Publishing, The Hague, 75-97.

van Kleunen M, Dawson W, Dostál P (2011) Research on invasive-plant traits tells us a lot. Trends in Ecology \& Evolution 26: 317.

Vilà M, Basnou C, Pyšek P, Josefsson M, Genovesi P, Gollasch S, Nentwig W, Olenin S, Roques A, Roy D, Hulme PE, Andriopoulos P, Arianoutsou M, Augustin S, Bacher S, Bazos I, Bretagnolle F, Chiron F, Clergeau P, Cochard PO, Cocquempot C, Coeur d'Acier A, David M, Delipetrou P, Desprez-Loustau ML, Didžiulis V, Dorkeld F, Essl F, Galil BS, Gasquez J, Georghiou K, Gudžinskas Z, Hatzofe O, Hejda M, Jarošík V, Kark S, Kokkoris I, Kühn I, Lambdon PW, Lopez-Vaamonde C, Marcer A, Migeon A, McLoughlin M, Minchin D, Navajas M, Panov VE, Pascal M, Pergl J, Perglová I, Pino J, Poboljšaj K, Rabitsch W, Rasplus JY, Sauvard D, Scalera R, Sedláček O, Shirley S, Winter M, Yannitsaros A, Yart A, Zagatti P, Zikos A (2010) How well do we understand the impacts of alien species on ecosystem services? A pan-European, cross-taxa assessment. Frontiers in Ecology and the Environment 8: 135-144. doi: 10.1890/080083.

Walther GR, Roques A, Hulme PE, Sykes MT, Pyšek P, Kühn I, Zobel M, Bacher S, BottaDukát Z, Bugmann H, Czücz B, Dauber J, Hickler T, Jarošík V, Kenis M, Klotz S, Minchin D, Moora M, Nentwig W, Ott J, Panov VE, Reineking B, Robinet C, Semenchenko V, Solarz W, Thuiller W, Vilà M, Vohland K \& Settele J (2009) Alien species in a warmer world: Risks and opportunities. Trends in Ecology \& Evolution 24: 686-693.

Williamson M (1996) Biological invasions. Chapman \& Hall, London, 256pp. 